\title{
Effect of Pulsed Ultrasound on Discoid Lupus Erythematosus
}

\author{
SHERIF E. BAZAN, M.Sc.*; MOHAMED M. KHALAF, Ph.D.**; MARWA A. EID, Ph.D.** and \\ MOHAMED T. REKABY, M.D.*** \\ Physical Therapist at Ministry of Health Hospitals*, The Department of Physical Therapy for Surgery, \\ Faculty of Physical Therapy, Cairo University, Giza** and The Department of Dermatology \& Andrology, \\ Faculty of Medicine, Al-Azhar University***, Egypt
}

\begin{abstract}
Background: Pulsed ultrasound has a lot of uses and in this study I used it to help patients with discoid lupus erythematosus to improve healing of scars.
\end{abstract}

Aim of Study: To determine the effect of pulsed ultrasound therapy on patients with Discoid lupus erythematosus.

Patients and Methods: Thirty patients (male and female), aged ranging from 20-40 years, suffering from discoid lupus erythematous participated in this study. They were selected randomly from Alhoud Almarsoud Hospital from first of May 2015 till thirty first of June 2015. They were randomly divided into 2 equal groups in number, one control group (A) and a study group (B). The control group (A) who did not receive the pulsed ultrasound therapy but they just received their traditional medical treatment, and they were instructed about avoiding sun light. The study group (B) received the ultrasound therapy (low intensity pulsed ultrasound) for 5-7 minutes every session, application was done 3 times per week for a month as a total period of treatment at Physiodiet Clinic in Nasr City. Their scars have been evaluated using Vancouver's Scar assessment Scale. Measurements were conducted before starting the treatment as a first record and at the end of the month of treatment as a second (final) record.

Results: Result showed that the ultrasound therapy was effective and fruitful in decreasing scar tissue as evidenced by the highly significant decrease in the total score of Vancouver Scar assessment scale.

Conclusion: Ultrasound therapy is beneficial in improving scars in Discoid lupus erythematosus.

Key Words: Low intensity - Pulsed ultrasound - DiscoidLupus erythematosus - Vancouver scale - Physical therapy.

\section{Introduction}

SYSTEMIC Lupus Erythematosus (SLE) is a chronic inflammatory disease of multifactorial

Correspondence to: Dr. Sherif E. Bazan, Physical Therapist at Ministry of Health Hospitals, Egypt etiology, which is characterized by the involvement of different organs and systems and by presenting important immunological disorders with autoantibodies. Although it can occur in both sexes, it has a higher incidence in women, mainly around 30 years of age [1].

The skin is a target organ that is affected by the disease in a variety of ways, so that cutaneous lesions constitute 4 of the 17 new criteria established by the Systemic Lupus International Collaborating Clinics (SLICC) in 2012, for the diagnosis of systemic lupus erythematosus [2]

Cutaneous lupus erythematosus CLE is categorized into three groups, including chronic (CCLE), subacute (SCLE), and acute (ACLE) forms. The most common manifestation of chronic CCLE is Discoid Lupus (DLE) [3] .

Discoid Lupus Erythematosus (DLE) is a chronic, scarring, atrophy producing, photosensitive dermatosis. DLE may occur in patients with systemic lupus erythematosus (SLE), and some patients $(<5 \%)$ with DLE progress to SLE. Discoid Lupus Erythematosus (DLE) represents the most common subtype of cutaneous lupus erythematosus. The disease predominantly affects sun-exposed sites such as the face, dorsal hands and scalp, although it can be disseminated [4] .

Although the etiology is poorly defined, it is assumed that different factors together favor the onset of Systemic Lupus Erythematosus, such as: Genetic factors, environmental factors (exposure to ultraviolet rays, viral infections, chemicals, and sexual hormones) and emotional factors [5]

Dermatohistopathological features of CLE variants span a morphological spectrum from dermoepidermal interface changes with vacuolization, 
dermal or subcutaneous perivascular lymphocytic infiltrates, sprinkling of neutrophils and neutrophilic dust beneath the basal membrane zone, basal membrane thickening, and interstitial mucin deposits as well as epidermal atrophy, follicular plugging or sclerotic changes in the dermis and subcutis [6]

\section{Material and Methods}

In Alhoud Almarsoud Hospital for two months, patients were randomly assigned into two equal groups (15 patients of each group) (study and control groups). Group (A): The control group received only their traditional medical treatment. Group (B): The study group received low intensity pulsed ultrasound therapy for 7-10 minutes 3 times per week for one month in addition to their traditional medical treatment.

\section{Inclusive criteria included:}

Patients were of both sexes (males and females). Age of the patients ranged from 20 to 40 years. The patients had to have grade 2 erythema in at least 3 locations, as defined by the Cutaneous Lupus Erythematosus Disease Area and Severity Index (CLASI) activity score.

\section{Exclusive criteria included:}

Patients who had been treated using chemo or radiotherapy. Patients who had associated disorders, pregnancy, immunodeficiency, HIV and diabetes or anemia. Patients suffered from mental or psychological disorders. Patients suffered from any systemic diseases that may interfere with the objectives of the study.

\section{Ethics:}

The protocol of this study was approved by the Ethical Committees of the Faculty of Physical Therapy (Cairo University, Egypt). Every patient signed an informed consent before starting the study. All participants were informed about the nature and the effect of the treatment and measurement tools. The patients were also instructed to report any side effects during the treatment sessions.

\section{Measurements:}

A- Vancouver scar assessment scale (VSS) Fig. (1):

Scars were assessed using the Vancouver assessment scale for all patients at the beginning and at the end of the study. The scale assessed 4 variables: Vascularity, height/thickness, pliability, and pigmentation. Finally, a total score was obtained for patients in both groups [7].

\begin{tabular}{ll}
\multicolumn{2}{l}{ The vancouver scar scale } \\
1- Vascularity & \\
Normal & 0 \\
Pink & 1 \\
Red & 2 \\
Purple & 3 \\
2- Pigmentation & \\
Normal & 0 \\
Hypopigmentation & 1 \\
Mixed & 2 \\
Hyperpigmentation & 3
\end{tabular}

$\begin{array}{ll}\text { 3- Pliability } & \\ \text { Normal } & 0 \\ \text { Supple } & 1 \\ \text { Yielding } & 2 \\ \text { Firm } & 3 \\ \text { Ropes } & 4 \\ \text { Contracture } & 5 \\ \text { 4- Height } & \\ \text { Flat } & 0 \\ <2 \mathrm{~mm} & 1 \\ 2-5 \mathrm{~mm} & 2 \\ >2 \mathrm{~mm} & 3\end{array}$

Fig. (1): The vancouver scar scale.

\section{Treatment procedures:}

Group A (control group) were received only medical treatment for discoid lupus erythematosus.

Group B (study group) subjects were comfortably seated in a chair or on a plinth with back support and feet on the floor. The areas of skin to be treated of were cleaned, the plug of the ultrasound unit was inserted into the main current supply.U.S device was switched ON and the U.S head was cleaned by alcohol.

- The parameters of U.S device were set as follow [8]:

- Mode: Pulsed.

- Intensity: $1-1.5 \mathrm{w} / \mathrm{cm}^{2}$.

- Frequency: 3M-HZ sonopuls 400 with a $5 \mathrm{~cm}^{2}$ sound head.

- Duration: 5-7 minutes according to scar area treated.

Sessions were carried on 3 times per week for one month.

\section{Statistical procedures:}

Descriptive statistics and $t$-test were conducted for comparison of the mean age between both groups. Chi squared test was conducted for comparison of distribution of affected sites between groups. $t$-test was conducted for comparison of pre and post-treatment mean values of VSS between groups. Paired $t$-test was conducted for comparison between pre and post-treatment mean values of VSS in each group. The level of significance for all statistical tests was set at $p<0.05$. All statistical measures were performed through the Statistical Package for Social Studies (SPSS) Version 19 for windows [9]. 


\section{Results}

VSS:

I-Pre treatment mean values of VSS of both groups (A and $B)$ :

The mean \pm SD VSS pre-treatment of the group A was $12.2 \pm 2.3$ and that of the group B was $11.8 \pm$ 1.85 . The mean difference between both groups was 0.4 . There was no significant difference in the VSS between group A and B pre-treatment ( $p=$ 0.6). (Table 1), Fig. (2).

\section{II-Pre and post-treatment mean values VSS of group A:}

The mean \pm SD VSS pre-treatment of the group A was $12.2 \pm 2.3$ and that post treatment was $9.8 \pm$ 2.78 . The mean difference between pre and posttreatment was 2.4 and the percent of improvement was $19.67 \%$. There was a significant decrease in the VSS in the group A post-treatment compared with pre-treatment $(p=0.004)$. (Table 2$)$, Fig. (3).

Table (1): Comparison of pre-treatment mean values of VSS between group A and B.

\begin{tabular}{|c|c|c|c|c|c|}
\hline & $\begin{array}{c}\text { VSS } \\
\mathrm{X} \pm \mathrm{SD}\end{array}$ & MD & $t$-value & $p$-value & Sig \\
\hline $\begin{array}{l}\text { Group A } \\
\text { Group B }\end{array}$ & $12.2 \pm 2.3$ & \multirow[t]{2}{*}{0.4} & \multirow[t]{2}{*}{0.52} & \multirow[t]{2}{*}{0.6} & \multirow[t]{2}{*}{ NS } \\
\hline & & & & & \\
\hline $\begin{array}{l}\text { MD }: 1 \\
p \text {-value : }\end{array}$ & $\begin{array}{l}\text { In Difference. } \\
\text { ability value. }\end{array}$ & & $\begin{array}{ll}\mathrm{SD} & : \mathrm{St} \\
t \text {-value } & : \mathrm{U} \\
\mathrm{NS} & : \mathrm{N}\end{array}$ & $\begin{array}{l}\text { dard Devia } \\
\text { baired } t \text {-valu } \\
\text { Significant }\end{array}$ & \\
\hline
\end{tabular}

Table (3): Comparison between pre and post-treatment mean values of VSS of group B.

\begin{tabular}{|c|c|c|c|c|c|c|}
\hline & $\begin{array}{c}\text { VSS } \\
\mathrm{X} \pm \mathrm{SD}\end{array}$ & MD & $\begin{array}{c}\% \text { of } \\
\text { improvement }\end{array}$ & $\begin{array}{c}t- \\
\text { value }\end{array}$ & $\begin{array}{c}p- \\
\text { value }\end{array}$ & Sig. \\
\hline $\begin{array}{l}\text { Pre } \\
\text { Post }\end{array}$ & $\begin{array}{l}11.8 \pm 1.85 \\
7.93 \pm 1.03\end{array}$ & 3.87 & 32.79 & 11.5 & 0.0001 & S \\
\hline $\begin{array}{l}\text { MD } \\
p \text {-valu }\end{array}$ & $\begin{array}{l}\text { : Mean. } \\
\text { : Mean Diff } \\
\text { e Probabilit }\end{array}$ & $\begin{array}{l}\text { ence. } \\
\text { value. }\end{array}$ & $\begin{array}{l}\mathrm{SD} \\
t \text {-value } \\
\mathrm{S} \quad:\end{array}$ & $\begin{array}{l}\text { Paired } \\
\text { Signifi }\end{array}$ & $\begin{array}{l}\text { Devia } \\
\text { value. } \\
\text { int. }\end{array}$ & \\
\hline
\end{tabular}

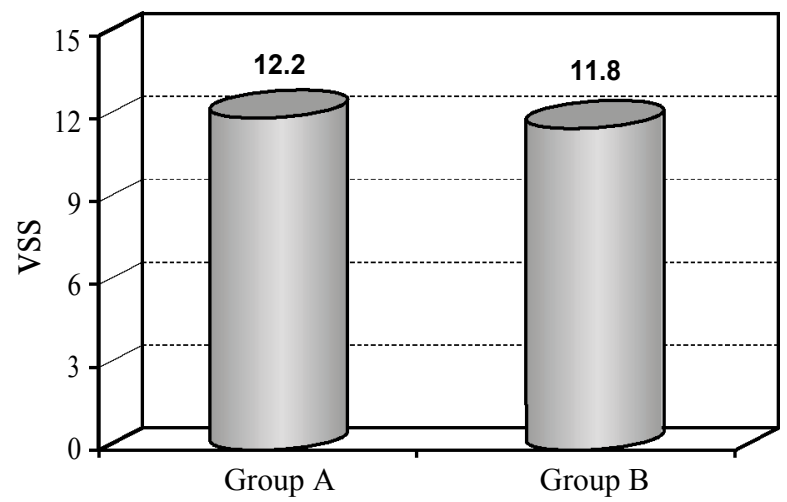

Fig. (2): Pre-treatment mean values of VSS of group A and B.

\section{III- Pre and post-treatment mean values VSS of} group $B$ :

The mean \pm SD VSS pre-treatment of the group $\mathrm{B}$ was $11.8 \pm 1.85$ and that post-treatment was $7.93 \pm$ 1.03. The mean difference between pre and posttreatment was 3.87 and the percent of improvement was $32.79 \%$. There was a significant decrease in the VSS in the group B post-treatment compared with pre-treatment ( $p=0.0001)$. (Table 3), Fig. (4).

\section{$I V$ - Post-treatment mean values of VSS of both groups ( $A$ and $B)$ :}

The mean \pm SD VSS post-treatment of the group A was $9.8 \pm 2.78$ and that of the group B was $7.93 \pm 1.03$. The mean difference between both groups was 1.87 . There was a significant decrease in the VSS in the group B compared with that of the group A post-treatment $(p=0.02)$. (Table 4$)$, Fig. (5).

Table (2): Comparison between pre and post-treatment mean values of VSS of group A.

\begin{tabular}{llccccc}
\hline & $\begin{array}{c}\text { VSS } \\
\mathrm{X} \pm \mathrm{SD}\end{array}$ & MD & $\begin{array}{c}\text { \% of } \\
\text { improvement }\end{array}$ & $\begin{array}{c}t- \\
\text { value }\end{array}$ & $\begin{array}{c}p \text { - } \\
\text { value }\end{array}$ & Sig. \\
\hline Pre & $12.2 \pm 2.3$ & 2.4 & 19.67 & 3.48 & 0.004 & $\mathrm{~S}$ \\
Post & $9.8 \pm 2.78$ & & & & & \\
\hline$\overline{\mathrm{X}}$ & : Mean. & & SD & : Standard Deviation. \\
MD & : Mean Difference. & $\begin{array}{l}t \text {-value }: \text { Paired } t \text {-value. } \\
p \text {-value : Probability value. }\end{array}$ & S & : Significant. &
\end{tabular}

Table (4): Comparison of post-treatment mean values of VSS between group $\mathrm{A}$ and $\mathrm{B}$.

\begin{tabular}{|c|c|c|c|c|c|}
\hline & $\begin{array}{c}\mathrm{VSS} \\
\mathrm{X} \pm \mathrm{SD}\end{array}$ & MD & $\begin{array}{c}t- \\
\text { value }\end{array}$ & $\begin{array}{c}p- \\
\text { value }\end{array}$ & Sig. \\
\hline $\begin{array}{l}\text { Group A } \\
\text { Group B }\end{array}$ & $\begin{array}{l}9.8 \pm 2.78 \\
7.93 \pm 1.03\end{array}$ & 1.87 & 2.43 & 0.02 & $\mathrm{~S}$ \\
\hline $\begin{array}{ll}\overline{\mathrm{X}} & : \mathrm{N} \\
\mathrm{MD} & : \mathrm{N} \\
p \text {-value }: \mathrm{P}\end{array}$ & $\begin{array}{l}\text { Difference. } \\
\text { bility value. }\end{array}$ & \multicolumn{4}{|c|}{$\begin{array}{ll}\mathrm{SD} & : \text { Standard Deviation. } \\
t \text {-value } & \text { : Paired } t \text {-value. } \\
\mathrm{S} & \text { : Significant. }\end{array}$} \\
\hline
\end{tabular}

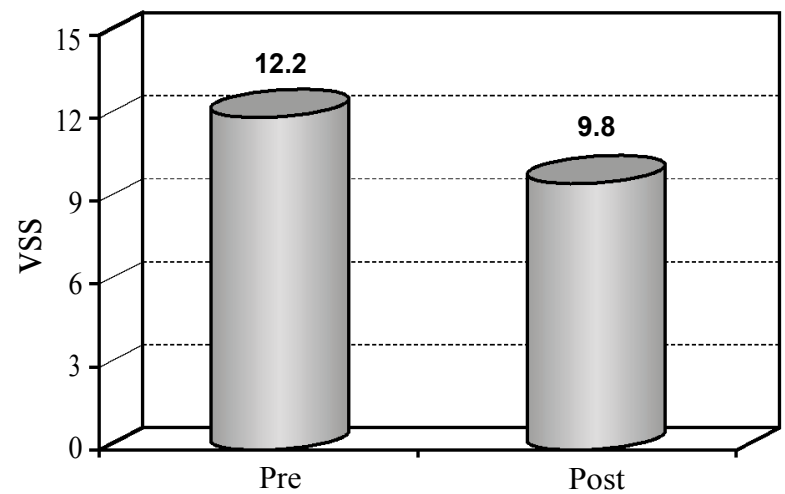

Fig. (3): Pre and post-treatment mean values of VSS of group A. 


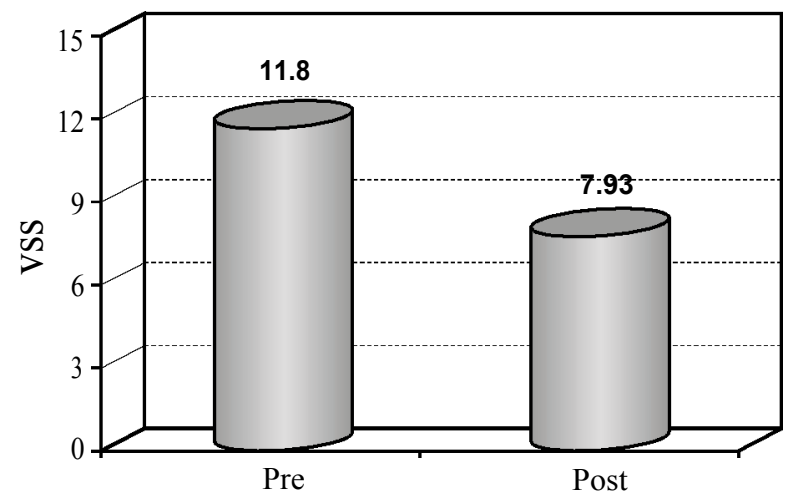

Fig. (4): Pre and post-treatment mean values of VSS of group B.

\section{Discussion}

Cutaneous Lupus Erythematosus (CLE) is a group of lupus variants in which cutaneous manifestations predominate. CLE may persist for years and cause impairment in quality of life, including vocational disability [10]

The Gilliam CLE classificationsystem divides Lupus Erythematosus (LE)-specific skinlesions into three broad categories: Acute cutaneous LE, subacute cutaneous LE (SCLE), and chronic cutaneous LE [11].

Skin lesions of CLE exhibit increased accumulationof dermal mucin [12]. Dermal mucin is composed of glycosaminoglycans (GAGs), which are long, polyanionic, polysaccharide polymers consistingof repeating disaccharide units. GAGs have been classifiedinto six different species depending on their structure: Chondroitinsulfate (CS), Hyaluronan (HA), dermatan sulfate (formerly CS-B), heparin, heparan sulfate, and keratan sulfate. All GAGs, except keratan sulfate, contain uronic acidresidues, which are detected by Hale's colloidal iron stain.GAGs are traditionally thought to provide mechanical resilienceto connective tissue [13].

Experimentation in vitro has revealed some of the immunologicfunctional characteristics of specific GAG species. Lowmolecular Weight (LMW) $\mathrm{HA}$, but not high molecular weightHA, activates macrophages and Dendritic Cells (DCs) andplays a role in immune cell recruitment to sites of inflammation. CS, on the other hand, promotes neutrophil activation [14] . CS also exhibits anti-inflammatory actions by counteracting the effects of Tumornecrosis Factor (TNF)-ct and interleukin (IL) -1 ( 3 in cell culture $[\mathbf{1 4 , 1 5}]$

It was found that DLE was the only condition with accumulationof both HA and CS. This increase in both HA and CS maycontribute to the more

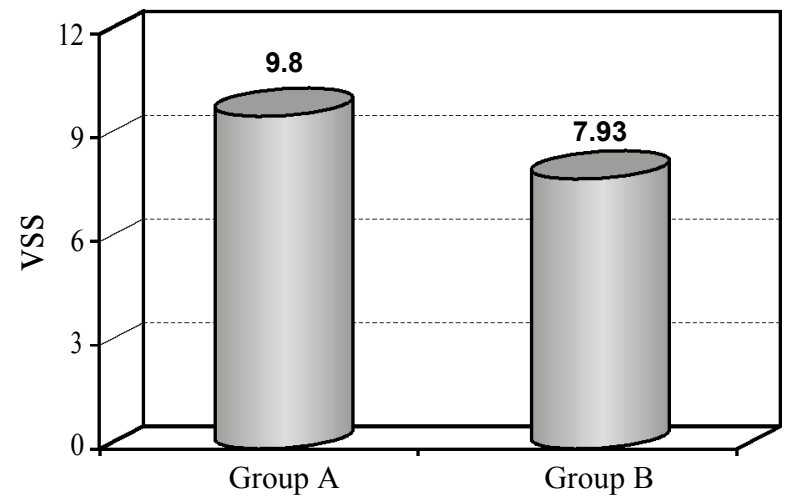

Fig. (5): Post-treatment mean values of VSS of group A and B.

resistant nature of this disease: Among CLE subtypes, DLE represents a disproportionatenumber of patients with disease refractory to current therapies. DLE patients have a higher Cutaneous Lupus Erythematosus Disease Area and Severity Index (CLASI) damage score than TLE and SCLE patients [16]. DLE lesions lead to scarring, whereas TLE and SCLE lesions heal without scarring [17] and the inflammatory infiltrate in DLE is muchmore extensive and deeper than in other CLE subtypes $[18,19]$.

GAGs are produced from fibroblasts as well as endothelialcells, and HA specifically is synthesized also by dendriticcells and keratinocytes. Inaddition, other immune cells such as T cells, B cells, andmonocytes have the ability to synthesize proteoglycans, particularly those consisting of chondroitin sulfate [13].

Ultrasound has proven to be an important therapeutic resource regarding musculoskeletal disease and is used both therapeutically as well as diagnostically in medicine. Ultrasound delivers energy through a pressure field generated by the transducer that causes the molecules in the transmission medium to oscillate or vibrate. Mechanical stimulation of cell membranes occurs during the energy delivery process [20]

According to Demir et al., and Lowe et al., ultrasound has demonstrated efficiency in the stimulation of fibroblasts, establishing that intensities from $0.1 \mathrm{~W} / \mathrm{cm}^{2}$ to $0.5 \mathrm{~W} / \mathrm{cm}^{2}$ accelerate the inflammatory phase of repair, suggesting that ultrasound intensities of about $0.5 \mathrm{~W} / \mathrm{cm}^{2}$ in pulsed mode and a frequency of $1 \mathrm{MHz}$ or $3 \mathrm{MHz}$ promote healing [8,21]

The results of this study agreed and were supported with the results of (Laura et al., [22]; De Olivera et al., [23]; Oliveira et al., [24] ; Samuels et al., [25] ; Voigt et al., [26] and Zhou et al., [27]). 
In a study, done by Laura et al., [22] lesional skin biopsies from patients with SCLE, DLE, and TLE, as defined by the Gilliam classification system, and DM were obtained from patients in the dermatology clinic at the Hospital of the University of Pennsylvania. Healthy control skin was acquired from patients at the Philadelphia VA Hospital. Hematoxylin and eosin (H \& E)-stained slides were prepared from all biopsies. Results showed thatglycosaminoglycans are increased in CLE and dermatomyositis skin lesions. Compared to control skin, CLE and DM lesions exhibitedincreased mucin accumulation. SCLE lesions generally showed a minor accumulation of GAGs in the upper dermis, while DLE lesions had a strikingelevation in Hale's staining throughout the dermis comparedto controls. This large accumulation of GAGs in DLE corresponded to a significant increase in the density of both HA and CS staining in DLE lesions.

In a study, done by De Oliveira et al., [23] was to assess the effect of low-intensity pulsed ultrasound on 1929 fibrolasts. The aim of the study was to analyse the effects with different ultrasound intensities in order to establish the ideal radiation level in cell cultures. Analysis of the results following ultrasound irradiation demonstrated that the effect of ultrasound with $0.6 \mathrm{~W} / \mathrm{cm}^{2}$ in pulsed mode at $10 \%$ (1:9 duty cycle) was statistically significant in relation to ultrasonic irradiation in pulsed mode at $20 \%$ ( $2: 8$ duty cycle) $(p<0.05)$. According to parameters used in the irradiation of cultivated fibroblasts, the pulse mode regime and the control of intensity are of fundamental importance for the optimal use of therapeutic ultrasound. Furthermore, low and medium intensities decreased cell damage, which establishes that acoustic pulsed energy induces the proliferation of fibroblast cells.

Another study, by Oliveira et al., [24] focused on the assessment of cytoskeleton and endoplasmic reticulum of fibroblast cells subjected to low-level laser therapy and low-intensity pulsed ultrasound. The aim of that study was to compare the effect of Low-Level Laser Therapy (LLLT) and LowIntensity Pulsed Ultrasound (LIPUS) on the cytoskeleton and endoplasmic reticulum of L929 cells. The results following LLLT and LIPUS demonstrate that ultrasound was more effective than laser on fibroblast cell cultures when the endoplasmic reticulum was assessed, whereas there was a better distribution of the filaments of the cytoskeleton in the cells subjected to laser irradiation.
In a study done by Samuels et al., [25] its purpose was to examine whether low frequency $(<100 \mathrm{kHz})$, low intensity $\left(<100 \mathrm{~mW} / \mathrm{cm}^{2}\right.$, spatial peak temporal peak) ultrasound can be an effective treatment of venous stasis ulcers. Twenty subjects were treated with either 20 or $100 \mathrm{kHz}$ ultrasound for between 15 and $45 \mathrm{~min}$ per session for a maximum of four treatments. Healing was monitored by changes in wound area. Subjects receiving $20 \mathrm{kHz}$ ultrasound for $15 \mathrm{~min}$ showed statistically faster $(p<0.03)$ rate of wound closure. The in vitro results indicated that $20 \mathrm{kHz}$ ultrasound at $100 \mathrm{~mW} / \mathrm{cm}^{2}$ caused an average of $32 \%$ increased metabolism $(p<0.05)$ and $40 \%$ increased cell proliferation $(p<0.01)$ after $24 \mathrm{~h}$ when compared to the control, non-treated cells. This work supported the notion that lowintensity, low-frequency ultrasound is beneficial for treating venous ulcers.

Voigt et al., [26] has been studied extensively ultrasound as a therapeutic agent in chronic wound healing. This systematic review and meta-analysis specifically examines low-frequency $(20-30 \mathrm{kHz})$ ultrasound delivered at either low or high intensity. The objective of this review was to determine whether low-frequency ultrasound used as an adjunctive therapy improves the outcomes of complete healing and reduction of size of chronic lower limb wounds. Results demonstrated that early healing (at $<5$ months) in patients with venous stasis and diabetic foot ulcers was favorably influenced by both high- and low-intensity ultrasound delivered at a low frequency-either via contact or noncontact techniques.

A study done by Zhou et al., [27] to identify the molecular mechanisms of low intensity pulsed ultrasound in human skin fibroblasts. In that study, they examined the effect of US on cell proliferation and the signaling mechanism mediating this effect in primary human foreskin fibroblasts. The results showed that US Induces DNA synthesis and cell proliferation in human skin fibroblasts.

\section{Conclusion:}

It was concluded that the low intensity ultrasound therapy is an effective treatment for scars in discoid lupus erythematosus.

\section{References}

1- DANCHENKO N., SATIA J.A. and ANTHONY M.S.: Epidemiology of systemic lupus erythematosus: A comparison of worldwide disease burden. Lupus, 15: 308-18, 2006.

2- ORBAI A.M., PETRI M., ALARCÓN G.S., GORDON C., MERRILL J.T., FORTIN P.R., et al.: Derivation and 
Validation of the Systemic Lupus International Collaborating Clinics Classification Criteria for Systemic Lupus Erythematosus Arthritis. Rheum., 64: 2677-86, 2012.

3- WERTH V.P., ZHANG W., DORTZBACH K. and SULLIVAN K.: Association of a promoter polymorphism of TNFalpha with subacute cutaneous lupus erythematosus and distinct photoregulation of transcription. J. Invest. Dermatol., 115: 726-30, 2005.

4- JAMES W.D., BERGER T. and ELSTON D.: Psoriasis. In: Andrews' Diseases of the skin. Clinical Dermatology (Odom RB, James WD, Berger T, eds), $10^{\text {th }}$ edn. Amsterdam: Elsevier, WB Saunders Co., 2006; 157-60. J. Athl. Train., Jul.-Sep., 37 (3): 293-9, 2002.

5- FREIRE E.A.M., SOUTO L.M. and CICONELLI R.M.: Medidas de avaliação em lúpus eritematoso sistêmico (Assessment measures in systemic lupus erythematosus) Rev. Bras. Reumatol., 51: 75-80, 2011.

6- WENZEL J., BRÄHLER S., BAUER R., BIEBER T. and TÜTING T.: Efficacy and safety of methotrexate in recalcitrant cutaneous lupus erythematosus: Results of a retrospective study in 43 patients. Br. J. Dermatol., 153: 157-62, 2005.

7- TYACK ZEPHANE, SIMONS MEGANE, SPINKS ANNILESE and WAISAK JASON: A systematic review of the quality of burn scar rating scales for clinical and research use. Pub: 2012-02-01.

8- DEMIR H., YARAY S., KIRNAP M. and YARAY K.: Comparison of the effects of laser and ultrasound treatments on experimental wound healing in rats. J. Rehabil. Res. Develop., 41: 721-8, 2004.

9- DEMIDENKO E.: Sample size and optimal design for logistic regression with binary interaction. Statistics in Medicine, 27: 36-46, 2008.

10- MELLER S., HOMEY B. and RUZICKA T.: Socioeconomic factors in lupus erythematosus. Autoimmun. Rev., 4: 242-6, 2005.

11- SONTHEIMER R.D. and PROVOST T.T.: Cutaneous manifestations of rheumatic diseases. Philadelphia: Lippincott Williams \& Wilkins, 2004.

12- ACKERMAN A.B., CHONGCHITNANT N., SANCHEZ J., GUO Y., BENNIN B. and REICHEL M.: Histologic diagnosis of inflammatory skin diseases: An algorithmic method based on pattern analysis. Baltimore: Lippincott Williams \& Wilkins, 2007.

13- TAYLOR K.R. and GALLO R.L.: Glycosaminoglycans and their proteoglycans: Host-associated molecular patterns for initiation and modulation of inflammation. FASEB J., 20: 9, 2006.

14- XU C.X., JIN H., CHUNG Y.S., SHIN J.Y., WOO M.A., LEE K.H., PALMOS G.N., CHOI B.D. and CHO M.H.: Chondroitin sulfate extracted from the Styela clava tunic suppresses TNF-alpha-induced expression of inflammatory factors, VCAM-1 and iNOS by blocking Akt/NF -jB signal in JB6 cells. Cancer Lett., 264: 93-100, 2008.

15- FIORAVANTI A. and COLLODEL G.: In vitro effects of chondroitin sulfate. Adv. Pharmacol., 53: 449-65, 2006.
16- MOGHADAM-KIA S., CHILEK K., GAINES E., COSTNER M., ROSE M., OKAWA J. and WERTH V.P.: Crosssectional analysis of a collaborative Web-based database for lupus erythematosusassociated skin lesions: Prospective enrollment of 114 patients. Arch. Dermatol., 145: 25560, 2009.

17- KUHN A. and SONTHEIMER R.D.: Cutaneous lupus erythematosus: Molecular and cellular basis of clinical findings. Curr. Dir. Autoimmun., 10: 119-40, 2008.

18- CROWSON A.N. and MAGRO C.: The cutaneous pathology of lupus erythematosus: A review. J. Cutan. Pathol., 28: 1-23, 2001.

19- WENZEL J., SCHMIDT R., PROELSS J., ZAHN S., BIEBER T. and TUTING T.: Type I interferon-associated skin recruitment of CXCR3+ lymphocytes in dermatomyositis. Clin. Exp. Dermatol., 31: 576-82, 2006.

20- LAI J. and PITTELKOW M.R.: Physiological effects of ultrasound mist on fibroblasts. Int. J. Dermatol., 46: 58793, 2007.

21- LOWE A.S., WALKER M.D., COWAN R. and BAXTER G.D.: Therapeutic ultrasound and wound closure lack of healing effect on X-ray irradiated wound in murine skin. Arch. Phys. Med. Rehabil., 82: 1507-11, 2001.

22- LAURA M. CHANG, PRATEESH MAHESHWARI, SHEILA WERTH, LANA SCHAFFER, STEVEN R. HEAD, CARRIE KOVARIK and VICTORIA P. WERTH: Identification and Molecular Analysis of Glycosaminoglycans in Cutaneous Lupus Erythematosus and Dermatomyositis. Journal of Histochemistry \& Cytochemistry, 59 (3): 336-45, 2011.

23- FRANCO De OLIVEIRA R., PIRES OLIVEIRA D.A. and SOARES C.P.: Effect of low-intensity pulsed ultrasound on 1929 fibroblasts. Arch. Med. Sci., Apr., 7 (2): 224-9. Doi: 10.5114/aoms.2011.22071. Epub 2011 May 17, 2011.

24- OLIVEIRA D.A., De OLIVEIRA R.F., MAGINI M., ZANGARO R.A. and SOARES C.P.: Assessment of cytoskeleton and endoplasmic reticulum of fibroblast cells subjected to low-level laser therapy and low-intensity pulsed ultrasound. Photomed. Laser Surg., Jun., 27 (3): 461-6. Doi: 10.1089/pho.2008.2290, 2009.

25- SAMUELS J.A., WEINGARTEN M.S., MARGOLIS D.J., ZUBKOV L., SUNNY Y., BAWIEC C.R., CONOVER D. and LEWIN P.A.: Low-frequency $(<100 \mathrm{kHz})$, lowintensity $\left(<100 \mathrm{~mW} / \mathrm{cm}^{2}\right)$ ultrasound to treat venous ulcers: A human study and in vitro experiments. J. Acoust. Soc. Am., Aug., 134 (2): 1541-7. Doi: 10.1121/1.4812875,2013.

26- VOIGT J., WENDELKEN M., DRIVER V. and ALVAREZ O.M.: Low-frequency ultrasound $(20-40 \mathrm{kHz})$ as an adjunctive therapy for chronic wound healing: A systematic review of the literature and meta-analysis of eight randomized controlled trials. Int. J. Low Extrem Wounds. Dec., 10 (4): 190-9. Doi: 10.1177/1534734611424648, 2011.

27- ZHOU S., SCHMELZ A., SEUFFERLEIN T., LI Y., ZHAO J. and BACHEM M.G.: Molecular mechanisms of low-intensity pulsed ultrasound in human skin fibroblasts. J. Biol. Chem., 279: 54463-9, 2004. 


\section{تآثير الموجات النابضة فوق الصوتية \\ على الذئبة الحمراء النابفر فوق القرية}

آجريت هذه الدراسة بهدف معرفة تآثير الموجات النابضة فوق الصوتية على الزئبة الحمراء القرصية. وقد شارك في هذه الدراسة ثلاثثن

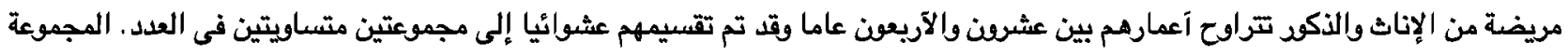

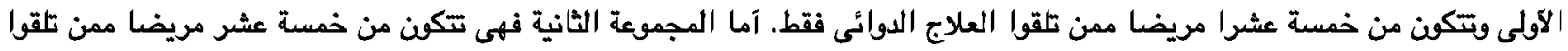

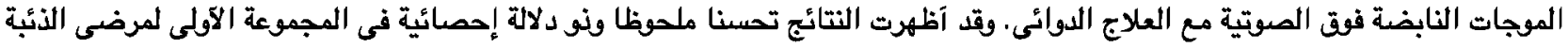
الحمراء القرصية عن المجموعة الثانية. 